\title{
Analysis of the factors that influence in the informal investors: Comparison of Spain and India in the period 2012-2016.
}

\author{
Mercedes Barrachina ${ }^{1}$, María del Carmen García Centeno² ${ }^{2}$ Carmen Calderón Patier ${ }^{3}$ \\ ${ }^{1}$ CEINDO, Law and Economics Program, San Pablo CEU University, Madrid, Spain. \\ ${ }^{2,3}$ San Pablo CEU University, Madrid, Spain \\ DOI: 10.29322/IJSRP.11.05.2021.p11302 \\ http://dx.doi.org/10.29322/IJSRP.11.05.2021.p11302
}

\begin{abstract}
In recent years, most sectors have benefited from an explosion in the creation of startups in different entrepreneurial environments. In relation with the entrepreneurship, there has been a growing interest in the role of informal investors in the creation of new companies with the objective of identifying the characteristics that could help governments and regulators to promote different measures that help economic growth. The objective of this analysis is to identify the factors that characterize the informal investors in Spain and India. The analysis was performed using data from the website "Global Entrepreneurship Monitor" (GEM) from the period 2012-2016 at the global individual level for Spain and for India. The method utilized to evaluate the data was a logistic regression. The purpose is to compare the existing differences between the factors that characterize an informal investor in different economic periods (pre-crisis, crisis, post-crisis), in two different entrepreneurial environments, such as Spain and India to identify measures or actions that can be implemented by the national and local organisms to promote informal investment and entrepreneurship. Findings identify clear differences between Spain and India in relation to the informal investor profile.
\end{abstract}

Index Terms- informal investment, entrepreneurship, Spain, India

\section{INTRODUCTION}

$I^{2}$ n recent years, most sectors have benefited from an explosion in the creation of startups in different entrepreneurial environments. In relation with the entrepreneurship, there has been a growing interest in the role of informal investors in the creation of new companies with the objective of identifying the characteristics that could help governments and regulators to promote different measures that help economic growth.

Several studies identify that informal investments (that is, those that cover the financing needs of business plans in their initial entrepreneurial stage) contribute to entrepreneurial activity at national level (Bygrave et al, 2002, Autio et al, 2003). In the literature reviewed, the concept of "informal investor" and "business angel" is used in a similar way. The term "business angel" was first used by William Wetzel, a professor at the University of New Hampshire in a study he conducted on the financing of entrepreneurs (Wetzel, 1983). This study identified "business angels" as the agents that finance companies at their earliest stage, in which other investors are reluctant to offer financing and identified the profile of "business angels" based on their demographic characteristics, preference patterns and expectations.

Regarding the use of the concept "informal investor" and "business angel" interchangeably, there are different opinions in the literature reviewed. The authors Mason and Harrison (2000) defined informal investors as "individuals with high purchasing power who, acting alone or formally or informally syndicated with others, invest their own money directly in an unquoted business with which they do not maintain a family relationship. " The main difference of this definition with a "business angel" is that it does not specify that informal investors actively participate in the projects they finance, so it does not consider the transfer of smart capital. This definition of "informal investor" also does not consider investments made in businesses of family or friends. However, not all authors think in this way, there are several authors who consider that investments in businesses of family, friends or people close to the entrepreneur ( $3 \mathrm{Fs}$ ) is also a form of investment and should be included, there is currently debate on the topic. For example, in the study conducted by Avdeitchikova (Avdeitchikova et at, 2008), it proposes a subdivision of the informal financing segment, also called informal venture capital, into 3 figures, first the business angel who are defined as investors who are actively involved and contribute smart capital to projects. Second, the informal investors which is mainly a group that includes not only the "business angel", but also the private investors that have a non-active involvement with the projects in which they invest. Last, the non-institutional investors which includes investments made by family and friends of the partners who lead the project.

However, according to the GEM project, a broad definition of the "informal investor" concept presented by Mason and Harrison (2000) is used and what is known as the 3Fs is included for its acronym in English (Family, Friends, Fools). This inclusion is because the micro-investments of these agents represent $80 \%$ of the external resources that start-ups need and therefore are important enough to be included in informal financing (Reynolds et al, 2003) .

In recent years, researchers have studied the characteristics of "informal investors" in several countries such as the United States (Aram, 1989), United Kingdom (Harrison and Mason, 
1992), Sweden (Landström, 1993), Finland (Lumme et al, 1996), Japan, (Tashiro, 1999), or Singapore (Wong and Ho, 2007). From these studies it is concluded that the typical profile of "informal investor" is defined as an entrepreneur or executive man (active or already retired) with a high level of income, entrepreneurial experience and extensive experience in the business world with the will to invest between 20,000 and 250,000 euros per project.

Among the studies that try to identify the factors that define the profile of an "informal investor", there are some that try to develop a classification system for these agents, where the first analysis of this type stands out by establishing 10 different categories (Gaston, RJ, 1989). Subsequently, other authors establish other types of classifications, the classification system of 9 types (Benjamin and Margulis, 2005), the one of 3 types (Mason, 2006), and the one of 5 types (Evanson and Beroff, 1998) being relevant.

According to the report of the Spanish Association of Business Angels of 2019, it highlights that in Spain $45 \%$ of investors have less than 5 investments, that $91 \%$ of investors consider training is important, in addition $70 \%$ have experience professional related to technology and finance, and in general they show a limited annual investment capacity, since $67 \%$ have less than 100,000 euros of investment per year.

In India the angel investment started many years ago and it is an increasing activity. This is also reflected in the number of rounds provided by the angel investors, from 79 in the period 2000-2008 to 193 in year 2015. Moreover, most of the angels investors are located in the South of India (almost 40\%) or in the West (almost 30\%), very concentrated compared to other countries, such as United States (Sabarinathan, 2019).

Overall, the article has been organized as follows. First, literature review supporting the research provided. Then, the research methodology and data collection have been highlighted along with the main results of this study, together with the discussion. Finally, conclusions, as well as limitations and future lines of research have been proposed.

\section{LITERATURE REVIEW}

Small and medium-sized companies are key in projecting inclusive and sustainable growth, also considering factors such as social cohesion. More specifically, in OECD countries, these types of companies, also known as SMEs, represent $99 \%$ of companies, $60 \%$ of employment, and are the main drivers in some cities and regions (OECD 2019).

The analysis of innovative start-ups in the different OECD countries (Breschi et al. 2018) reports that there are significant differences between countries in the education of start-ups. Likewise, it is stated that the political priority in all OECD countries aims to create the right conditions for innovative companies to grow and prosper.

There are also researchers who focus their study on analysing temporally and geographically different aspects related to entrepreneurship. Beynon et al., (2016), presents a novel longitudinal study of entrepreneurship attitudes and activities, using data from the GEM database, covering a total of 54 countries. Khyareh and Torabi (2018) study the effect of elements of Iran's entrepreneurial ecosystem, examining the ecosystem problems that hampered economic growth.
Regarding the study of entrepreneurship, several data sources used in the literature have been identified. One of the main ones has been the GEM (Global Entrepreneurship Monitor) database, which is the world's most important observatory on entrepreneurship. It started in 1999 and since then, it measures the entrepreneurial dynamics in more than 100 countries thanks to a common methodology, with which it evaluates characteristics, attitudes and motivations (Asociación RED GEM España 2019). Specifically, the GEM was created in September 1997 as a joint research initiative between Babson College and London Business School. Its main objective was to bring together the best academics in the world in entrepreneurship and create a database that would allow analysing the relationship between entrepreneurship and economic growth. Initially, GEM focused on the G7 countries (Canada, France, Germany, Italy, Japan, the United Kingdom and the United States) and additionally three more countries were added, due to the origin of the selected academics (Denmark, Finland and Israel) (Reynolds 1999).

Related to the investment process, there are different authors in the literature explaining the process of an investment in a company. Van Osnabrugge and Robinson (2000), suggested that the investment process could be summarized in 8 stages: finding deals, investment motivations, investment criteria, initial screening, due diligence, negotiations and actual investment, post investment monitoring, exiting and realizing returns. It is interesting to mention that different studies referred to investment opportunities acceptance rates between $6-22 \%$ for angels, meanwhile this rate is lowered to $1-2 \%$ in the case of venture capitalists.

The relationship between risk capital and public policies is analysed, among other authors, by McGlue (2002), who considered the key questions faced by those responsible of formulating public policies in the European Union to stimulate risk capital. On the other hand, Bettignies and Brander (2007) examined the entrepreneur's choice between bank financing and venture capital.

Bosma et al. (2018) highlighted the importance of venture capital related to entrepreneurship and economic growth in Europe, while Torres and Godinho (2019) analysed the importance of venture capital and highlighted how the United States and China are responsible for two-thirds of investments performed while in Europe this figure is much lower.

The advantages and disadvantages offered by venture capital and the new frontiers of financing for entrepreneurs are analysed by Bellavitis et al. (2017). In addition, Hannan et al. (1996) identified the main disadvantages of venture capital for the investee company and for the company that makes the investment.

Recently, the researches related to the entrepreneurial finance have been developed considerably. For example, Cumming et al. 2019 and also Hervé et al. 2019, evaluated the determinants of investment decisions in investment-based crowdfunding campaigns (stocks and bonds). Also, it is interesting the analysis on the attractiveness of companies that focus on sustainability in capital crowdfunding processes (Vismara 2019) or use a machine learning approach to predict the success of a crowdfunding project (Yeh and Chen 2020).

The process of the investment decision is not always easy. There are many examples in the literature. Mason et al (2002), exposed that most of the busines angels (around 90\%) are looking 
for making new investments, however, they are not able to find deals that could meet with their criteria investment, with enough quality or having a situation in which they can negotiate good investment terms with the entrepreneurs. Those factors could be utilized by the policy makers to find solutions to offer small firms the capacity to access to business angels to finance their businesses.

Evaluating India's situation, it is remarkable the huge economic growth occurred in India in the 20 years. The role of business angels in India is growing constantly. It is interesting that in 2015 the initial capital provided to start-ups in India by business angels or informal investors grew $85 \%$ compared to the previous year, revealing the increasing role that those agents play in the economic growth. According to Habeeb and Ahmad (2015), the startups found by entrepreneurs are considered as the economic force needed in India and in general, the country is observed to be the youngest "Startup Nation", even though the survival rate of those companies is really low. Different initiatives were taken by the Indian government since 2014 with the purpose of building an entrepreneurial economy.

Economic growth in India is affected by the emerging middle class, the cost competitiveness, and the large talent tool. There are different constraints against doing business in India, such as for example the access to finance, the complexity to register a property in the country. India has worked during the last years in facilitate as much as possible the procedure related with a business, for example making easier the procedure for forming a company, reducing the time and cost for obtaining construction permits or enabling post clearance audits to make trading easier across borders. (World Bank, 2020).

Social entrepreneurship is a relevant entrepreneurship area in India and there are authors in the literature that have studied the critical factors in the process. Satar and John (2019), described the most important factors influencing social entrepreneurship. Some of those factors are the human capital, the legal support, the marketing, the leadership or the innovative financing.

\begin{tabular}{|c|c|c|}
\hline Variable & Description & Source \\
\hline gender & $\begin{array}{l}\text { Gender. This variable will be filtered to } \\
\text { match the female gender (value } 1 \text { ). }\end{array}$ & GEM Database \\
\hline age & Age of the respondent & GEM Database \\
\hline hhsize & Number of members in household & GEM Database \\
\hline gemwork & $\begin{array}{l}\text { Education level: } 1 \text { if secondary or higher } \\
\text { education }\end{array}$ & GEM Database \\
\hline gemeduc & $\begin{array}{l}\text { Respondent income. } 1 \text { if it is in the } \\
\text { highest } 33 \mathrm{rd} \text { percentile }\end{array}$ & GEM Database \\
\hline gemhhinc & $\begin{array}{l}\text { Work status. } 1 \text { if the respondent is } \\
\text { employed full time }\end{array}$ & GEM Database \\
\hline ownmge & $\begin{array}{l}1 \text { if the respondent has confidence in } \\
\text { his/her entrepreneurial skill }\end{array}$ & GEM Database \\
\hline suskill & $\begin{array}{l}1 \text { if the respondent personally knows } \\
\text { someone who started a firm in the past } \\
\text { two years }\end{array}$ & GEM Database \\
\hline knowent & $\begin{array}{l}1 \text { if the respondent has managed a } \\
\text { company }\end{array}$ & GEM Database \\
\hline busang & $\begin{array}{l}1 \text { if the respondent has personally acted as } \\
\text { a business angel in the past } 3 \text { years }\end{array}$ & GEM Database \\
\hline
\end{tabular}

The business angels play an important role in the Indian economy and there are usually characterized by 2 different profiles (Rao and Kumar, 2016). One profile is dedicated full time to the investment activities, usually called pure angels and the other profile is defined by the entrepreneurs who become investors, which are called super angels. Another remarkable point is that the Indian Angel network is one of the most prominent is the world with 400 membership. The cities in which the activities performed by those agents are based, are mainly Delhi, Bangalore, Mumbai, but also Chennai, Hyderabad and Pune. Sabarinathan, (2019) mentioned that angel investment has been present in India for a long time, mainly for filling the gap in the capital market that now is starting to be covered by venture capital and private equity industries.

\section{DATA AND METHODOLOGY}

The purpose of this work is to analyze the factors that characterize the "informal investor" in Spain and India, analyzing different variables (social, economic, perceptual, etc.) in the period 2012-2016. Data from the Global Entrepreneurship Monitor (GEM) will be used covering the different periods: the period of the economic crisis (2012-2014) and the first period after that crisis covering the years 2015-2016. Below more details about the periods analyzed can be found:

- Period 1: crisis (2012-2014), analyzing a total of 20,161 records for Spain and a total of 8,615 for India.

- Period 2: post-crisis (2015-2016), analyzing a total of 28,646 records for Spain and a total of 6,802 for India.

The following table shows the variables that have been considered in this work: 
The general model, utilized a logistic regression and can be defined as:

Informal investor $=\alpha+\beta_{1}$ gender $+\beta_{2}$ age $+\beta_{3}$ age $e^{2}+\beta_{4}$ hhsize $+\beta_{5}$ gemwork $+\beta_{5}$ gemeduc $+\beta_{6}$ gemhhinc + $\beta_{7}$ ownmge $+\beta_{8}$ suskill $+\beta_{9}$ knowent $+\varepsilon$

The dependent variable analyzed will be busang, which identifies the propensity for informal investment.

The analysis uses a logistic regression model to analyze which of the proposed factors affect the probability of making the decision to invest as an informal investor and to what extent each variable does.

The main hypotheses that arise, regardless of the economic situation, are the following:

1. Being a woman negatively influences the decision to act as an informal investor.

2. Being of high age has a negative influence on the decision to act as an informal investor.

3. The greater the number of members in the household, the less likely they are to act as an informal investor.

4. Being employed full time has a positive influence on investing in third-party ventures.

5. Having higher education increases the possibility of acting as an informal investor.
6. Individuals with a high salary have a greater propensity to act as investors in other people's ventures.

7. Having management experience increases the probability of acting as an informal investor.

8. Individuals with confidence in their abilities are more likely to act as informal investors.

9. Knowing other entrepreneurs or having the necessary skills to undertake, facilitates acting as an investor in third-party ventures.

\section{RESULTS}

The model used analyzes the effect of the different variables analyzed in general informal investment in Spain and India during periods with different economic conditions (crisis and post-crisis), during the years 2012-2016.

The results of the logit model for the different periods analyzed are shown in the following tables for Spain and for India:

\begin{tabular}{lllll}
\hline Variables & Period 1 & \multicolumn{3}{c}{ Period 2 } \\
\hline gemwork & Coef. & $\mathbf{P}>\mathbf{z}$ & Coef. & $\mathbf{P}>\mathbf{z}$ \\
gemhhinc & 0.0576 & 0.5175 & 0.3309 & 0.0000 \\
uneduc & 0.4171 & 0.0000 & 0.5308 & 0.0000 \\
suskill & 0.4156 & 0.0000 & 0.2320 & 0.0051 \\
knowent & 0.6867 & 0.0000 & 0.6081 & 0.0000 \\
ownmge & 1.2383 & 0.0000 & 1.1987 & 0.0000 \\
gender & -0.3912 & 0.0038 & -0.3462 & 0.0014 \\
age & -5.1786 & 0.0000 & -0.1219 & 0.0778 \\
age & -0.0136 & 0.5913 & -0.2566 & 0.0000 \\
hhsize & 0.0005 & 0.0874 & 0.0032 & 0.0000 \\
a & 0.0200 & 0.5386 & -0.0217 & 0.4034
\end{tabular}

Table 1. Result of the logit model for the different periods analyzed for Spain

\begin{tabular}{lllll}
\hline Variables & Period 1 & \multicolumn{3}{c}{ Period 2 } \\
\hline & Coef. & $\mathbf{P}>\mathbf{z}$ & Coef. & $\mathbf{P}>\mathbf{z}$ \\
gemwork & 0.2615 & 0.2340 & 0.7764 & 0.0000 \\
gemhhinc & 0.1403 & 0.4500 & 1.1699 & 0.0000 \\
uneduc & -0.5918 & 0.0167 & -0.4981 & 0.0311 \\
suskill & 0.3298 & 0.0800 & 0.3794 & 0.0142 \\
knowent & 0.9494 & 0.0000 & 1.1779 & 0.0000
\end{tabular}




$\begin{array}{lllll}\text { ownmge } & 0.7900 & 0.0003 & 1.6511 & 0.0000 \\ \text { gender } & -0.4717 & 0.0202 & 0.0633 & 0.6194 \\ \text { age } & -0.2116 & 0.0000 & -0.2400 & 0.0000 \\ \text { age } & 0.0025 & 0.0000 & 0.0028 & 0.0000 \\ \text { hhsize } & 0.0111 & 0.7670 & -0.1306 & 0.0010\end{array}$

Table 2. Result of the logit model for the different periods analyzed for India

Analyzing the results, first, it is important to conclude that for both countries for the analyzed periods, age (age variable) has a negative and significant influence while squared age (variable $a g e^{2}$ ) is a significant and positively influenced variable, which implies that at an older age, the lower the possibility of acting as an informal investor, regardless of the economic situation of the country, confirming hypothesis 2 . This fact occurs until a certain age of the individual, for this purpose, the variable $a g e^{2}$ was created in order to analyze the influence of the decision to become an informal investor, intuiting that the relationship is not linear, but rather quadratic, that is, the relationship that has been found is decreasing but at increasing rates. In both countries, age behaves like a parable regarding the decision to become an informal investor, that is, at a higher age, less likely to become an investor, until reaching a maximum limit, where the relationship is no longer direct, and it becomes inversely proportional. This fact could be explained under different premises such as the decision to take a different work path, having the basic needs covered and wanting to invest in new technologies or the need to get involved in projects for personal hobby ... etc. It is worth noting that the coefficient of the analyzed variable is much higher in India than in Spain, considering absolute values in period 1 , however the value has similar absolute values for period 2 for both countries. It is therefore concluded that in period 1 age was a more important variable in India than in the Spain when deciding to act as an informal investor.

Analyzing the effect of the variable related with the gender in the decision to act as an informal investor in Spain and in India, being a woman (gender variable takes value 1), negatively influences the decision to act as an informal investor, in periods 1 partially qualifying the hypothesis 1 raised. For both countries, this variable is not significant in period 2 evaluated.

The size of the household (hhsize variable), is not significant for Spain, however, it is significant for India, only for the second period analyzed (2015-2016). Moreover, apart from being significant it is also negative for the mentioned period, which means that the larger the household size, the lower the possibility that the respondent will make the decision to invest in entrepreneurial activities, partially confirming hypothesis 3 .

Regarding the level of education (uneduc variable) differences are observed in both countries. In Spain, in both periods, the variable related to the level of education is significant and positive which implies that the higher the level of education the greater the probability of being an informal investor This result qualifies the hypothesis 5 raised. However, in India, the level of education (uneduc variable), it is concluded that for all periods analyzed, it is a significant variable, with a negative coefficient and with different importance depending on the period analyzed. This result shows that, in general, the higher the level of education, the lower the possibility of carrying out investment activities in the india, rejecting hypothesis 5 .

The salary, represented with the gemhinc variable, analyzes the effect of the respondent's salary on his decision to act as an informal investor. The gemhinc variable takes the value 1 , in case the respondent has a salary in the 33rd highest percentile. For Spain, this variable is significant and with a positive effect regardless of the economic situation, confirming hypothesis 6 , However, for India this variable is significant only in period 2, having a positive effect as well. Analyzing the coefficient of the mentioned variable in the different economic periods, it is observed that in Spain, it is in period 2 when the salary variable has a major influence. This may be because after a period of crisis, potential investors with a medium salary prefer to invest in other lower risk options or that they do not have the necessary amount to invest in entrepreneurship activities in Spain.

The employment status, represented with the gemwork variable influences differently depending on the economic period analyzed, and the country. In Spain and India, in the period 1 analyzed, the variable is not significant, however, for period 2 , it is indeed significant and with a positive coefficient, partially qualifying hypothesis 4 . This could be the result of having a stable position, with a periodic income that can be used as a support to act as an informal investor and participate in an entrepreneurial activity. .

For the 2 periods analyzed and for both countries, knowing other entrepreneurs personally (knowent variable) is a significant and positive influence the decision of becoming an informal investor, confirming hypothesis 9 . In addition, this variable is the most important explanatory factor in the 2 periods. This fact has already been confirmed in other analyzes carried out with data from Finland (Maula et al, 2005) or with a sample of data from multiple countries of the year 2001 (Wong et al, 2005).

Likewise, in Spain trust (suskill) is a significant and positive variable regardless of the economic situation of the country, confirming hypothesis 8, while in India, it is a positive variable, but it is only significant in the second period, clarifying hypothesis 8 .

Finally, the fact of having managed a company, represented in the model with the ownmge variable has different results in Spain and in India. In Spain, it is a significant variable in both periods analyzed, however the coefficient is negative in both as well. However, in India, for both periods, this a significant variable but with a positive influence 2 . This result partially qualifies hypothesis 7 . This may be because after the crisis period, the factors that influence the decision to act as an informal investor in entrepreneurial activities change considerably. In addition, in India for the period 1 and 2, the analyzed variable is one of the most important explanatory factors of the analyzed model, 
emphasizing the importance of management experience in making investment decisions.

\section{DISCUSSION}

The main aim of this research was to identify the factors that influence the decision to become an informal investor in both Spain and India.

In this working, the importance of informal investor in the entrepreneurship has been exposed, which makes this role to be important for the economy in general as it is one of the main financing ways for the startups.

According to the model analyzed, it is therefore concluded that the variables that have a negative influence in Spain, regardless of the period analyzed, are age (age), gender (gender) and the previous experience in managing a business (ownnmge), while India, in addition to those mentioned, the variables related to education (uneduc) and size of the family (hhsize) but depending on the period evaluated, also negatively influence.

The variables that positively influence Spain are the employment status (gemwork), salary level (gemhhinc), educational level (uneduc), trust (suskill) and meet entrepreneurs personally (knowent)). The variables that present the highest coefficients in the analyzed model are, for period 1 and 2, knowing the entrepreneur personally (knowent) and trust (suskill).

The variables that positively influence in India the decision to become an informal investor are the salary level (gemhhinc), trust (suskill), personally know the entrepreneur (knowent) and have managed a company (ownmge), when does variables are signficant. The variables that present the highest coefficients (in absolute value) in the model related to India are knowing the entrepreneur personally (knowent) and the variables related to having managed a company (ownmge) for both period analyzed.

\section{CONCLUSION}

The main aim of this research was to identify the main characteristics for informal investors in Spain and India and find similarities and differences between them, using different variables: economical, behavioral, or educational.

In this work, the importance of entrepreneurship in the economy has been exposed, which makes it extremely useful to know the key factors in business angels or informal investors and it will help authorities to promote entrepreneurship investment in different sectors, executing different economic policies.

This analysis contributes to the literature in 2 ways. The first contribution is focused on validating the utilization of a logistic regression model with the purpose of evaluating entrepreneurial information from different countries, specifically in this case, for Spain and India, in a period when the variables evaluated are available. The second way to contribute is related to the novel comparison between the two countries selected, and this can be seen as a way to extend the existing literature related to entrepreneurship, and at the same the comparison provides information about the details of the entrepreneurship in the different regions. This type of information and comparison could be useful for different levels of policy makers and governments to take decisions based on data related to the support of the entrepreneurship with the main purpose of collaborating in helping the economy to grow.

There are several limitations to the results of this study. This analysis is subject to the limitations found during the execution of the analysis, mainly related with the amount of data available. Even though, the initial idea was to consider the period 2000-2016, the data from the GEM databases was not available for both countries, so the scope of the analysis was restricted to period 2012-2016. Moreover, a total of 20 different variables where considered, however, not all of them were having enough cases available, so those variables were discarded.

Based on the results obtained and considering that the topic of entrepreneurship is booming due to its relationship with economic growth, for future research, it would be interesting to extend the conclusions to the whole region, evaluating the Asian informal investor characteristics (including main countries such as Singapur, China, Thailand, Japan ...etc.) and also identifying the similarities with the American entrepreneurial model (United States, Mexico, Canada..etc). A very interesting option to extend this work would be to create a database with extended information about informal investors or business angels in general, in which the information related to investment types, return of investments, money invested, type of collaboration within the startup, regions, professional background of the investor would be fulfilled.

\section{REFERENCES}

[1] (Aram, 1989) Aram, J. D. (1989). Attitudes and behaviors of informal investors toward early-stage investments, technology-based ventures and coinvestors. Journal of Business Venturing, 4(5) , 333-347.

[2] (Asociación RED GEM España, 2019). Asociación RED GEM España (2019). Informe Global Entrepreneurship (GEM) España 2018-2019.

[3] (Autio et al, 2003) Autio, E., Wong, P. K., \& Reynolds, P. (2003). National factors influencing the prevalence of "high-potential" start-ups. NUS Entrepreneurship Centre Working Paper, Volume 11

[4] (Avdeitchikova et al, 2008) Avdeitchikova, S., Landström, H., \& Mansson, N. (2008). What do we mean when we talk about business angels? some reflections and definitions and sampling. Venture Capital: An International Journal of Entrepreneurial Finance, 10(4), 371-394.

[5] (Bellavitis et al, 2017). Bellavitis, C., I. Filatotchev, D.S. Kamuriwo, and T Vanacker. (2017). "Entrepreneurial finance: new frontiers of research and practice." Venture Capital 19(1-2): 1-16. doi: 10.1080/13691066.2016.1259733.

[6] (Benjamin and Margullis, 2005). Benjamin, G. A., \& Margullis, J. B. (2005) Angel capital: How to raise early-stage private equity financing. John Wiley \& Sons, 141-179.

[7] (Bettignies and Brander, 2007). Bettignies, J.E and Brander, J.A. (2007). "Financing entrepreneurship: Bank finance versus venture capital". Journal of Business Venturing 22(6): 808-832 doi:10.1016/j.jbusvent.2006.07.005.

[8] (Beynon et al, 2016). Beynon, M.J.; Jones, P. and Pickernell, D. (2016). Country-based comparison analysis using fsQCA investigating entrepreneurial attitudes and activity. Journal of Business Research, Vol. 69, Issue 4, pp. 1271-1276.

[9] (Bosma et al, 2018). Bosma, N., J. Content, M. Sanders, and E. Stam. (2018). "Institutions, entrepreneurship, and economic growth in Europe." Small Business Economics 51: 483-499.

[10] (Breschi et al, 2018). Breschi, S.; Lassébie, J. and Menon, C. (2018), A portrait of innovative start-ups across countries. OECD Science, Technology and Industry Working Papers, No. 2018/02, OECD Publishing, Paris.

[11] (Bygrave et al, 2002) Bygrave, W., Hay, M., Ng, E., \& Reynolds, P. (2002). A study of investing in 29 nations composing the global entrepreneurship monitor. Paper presented at the Kauffman Entrepreneruship Research Conference, Boulder, CO. Venture Capital: An International Journal of Entrepreneurial Finance, 5(2), 101-116. 
[12] (Cumming et al, 2019). Cumming, D., M. Deloof, S. Manigart, and M. Wright. (2019). "New directions in entrepreneurial finance." Journal of Banking \& Finance 100: 252-260.

doi:10.1016/j.jbankfin.2019.02.008.

[13] (Evanson and Beroff, 1998). Evanson, D. R., \& Beroff, A. (1998). Heaven sent: Seeking an angel investor? Here's how to find a match made in heaven. Entrepreneur.

[14] (Gaston, 1989) Gaston, R. J. (1989). Finding venture capital for your firm: A complete guide. John Wiley \& Sons.

[15] (Habeeb and Ahmad, 2015). Habeeb, S. and Ahmad, N. (2015). Impact of "fund of funds" and other iniciatives in building entrepreneurial economy of emerging India: a comparison with China.

[16] (Hannan et al, 1996). Hannan, M.T., J.N. Barron, and M.D. Burton. 1996. "Inertia and change in the early years: employment relations in young, hightechnology firms." Industrial and Corporate Change 5: 503-535.

[17] (Harrison and Mason, 1992). Harrison, R. T., \& Mason, C. M. (1992). International perspectives on the supply of informal venture capital. Journal of Business Venturing, , 7(6), 459-475.

[18] (Hervé et al, 2019). Hervé, F., E. Manthé, A. Sannajust and, A. Schwienbacher. 2019. "Determinants of individual investment decisions in investment based crowdfunding." Journal of Business Finance and Accounting. 46: 762-783. doi:10.1111/jbfa.12372

[19] (Khyareh and Torabi, 2019). Khyareh, M. and Torabi, H. (2019). Investigating the Role of Entrepreneurship Ecosystem in Iran's Economic Growth. The IUP Journal of Entrepreneurship Development, Vol. 15, Issue 4, December 2018, pp. 7-25. Available at SSRN: https://ssrn.com/abstract=3396288.

[20] (Landström, 1993) Landström, H. (1993). Informal risk capital in Sweden and some international comparisons. Journal of Business Venturing, 8(6), 525-540.

[21] (Lumme et at, 1996) Lumme, A., Mason, C., \& Suomi, M. (1996). The returns from informal venture capital investments: An exploratory study. Journal of Entrepreneurial and Small Business Finance, 5(2), 139-158.

[22] (Mason et al. 2002) Mason, C.M., Colin, M. and Harrison, R.T. (2002). Barriers to investment in the informal venture capital sector, Entrepreneurship and Regional Development, 14(3), 271-287

[23] (Mason, 2006) Mason, C. M. (2006). In Parker S. (Ed.), The life cycle of entrepreneurial ventures. Informal Sources of Venture Finance, 259-299.

[24] (Mason and Harrison, 2000) Mason, C. M., \& Harrison, R. T. (2000). Informal venture capital and the financing of emerging growth businesses. The blackwell handbook of entrepreneurship, Oxford: Blackwell, 221-239.

[25] (Maula et al, 2005) Maula, M., Autio, E., \& Arenius, P. (2005). What drives micro-angel investments? an examination of the determinants of family and nonfamily investments. Small Business Economics, 25(5), 459-475.

[26] (McGlue, 2002). McGlue, D. (2002). "The funding of venture capital in Europe: issues for public policy." Venture Capital 4(1): 45-58. doi: 10.1080/13691060110091246.

[27] (OECD, 2019). OECD, SME and Entrepreneurship Outlook 2019.
[28] (Rao and Kumar, 2016). Rao, S. V. R., \& Kumar, L. (2016). Role of Angel Investor in Indian Startup Ecosystem. FIIB Business Review, 5(1), 3-14. https://doi.org/10.1177/2455265820160101

[29] (Reynolds, 1999). Reynolds, P. (1999). Global Entrepreneurship Monitor: (1999) Executive Report. https://doi.org/10.13140/RG.2.1.4860.6247.

[30] (Reynolds et al, 2003). Reynolds P., M. Hay, W. Bygrave, S. Camp and E. Autio, (2003), Global Entrepreneurship Monitor 2001 Executive Report, Wellesley - London: Babson College, London Business School and Kauffman Foundation.

[31] (Sabarinathan, 2019). Sabarinathan, G. (2019). Angel Investments in India Trends, Prospects and Issues in the Current Economic Backdrop A Background Note. IIMB Management Review. 31 10.1016/j.iimb.2019.01.001.

[32] (Satar and John, 2019). Satar, M. \& John, S. (2019). The critical success factors of social entrepreneurship in India: An empirical study. International Journal of Entrepreneurship and Small Business. 37. 309-341. 10.1504/IJESB.2019.101103.

[33] (Tashiro, 1999) Tashiro, Y. (1999). Business angels in japan. Venture Capital: An International Journal of Entrepreneurial Finance, 1(3), 250-273.

[34] (Torres and Godinho, 2019). Torres, P. and, P. Godinho (2019), “Opportunity entrepreneurship, oil rents and control of corruption." Journal of Enterprising Communities: People and Places in the Global Economy 13(5): 647-667. doi:10.1108/JEC-07-2019-0067.

[35] (Van Osnagrugge and Robert, 2000). Van Osnagrugge, M. and Robert J.R. (2000), Angel Investing: Matching Startup Funds with Startup Companies-The Guide for Entrepreneurs and Individual Investors, Jossey Bass Business and Management Series, John Wiley and Sons

[36] (Vismara, 2018). (Vismara, S. 2018). "Sustainability in equity crowdfunding." Technological Forecasting and Social Change 141: 98-106. doi: 10.1016/j.techfore.2018.07.014.

[37] (Yeh and Chen, 2020). Yeh, J.Y. and, C.H. Chen. (2020) "A machine learning approach to predict the success of crowdfunding fintech project." Journal of Enterprise Information Management, Vol. ahead-of-print No. ahead-of-print. doi:10.1108/JEIM-01-2019-0017.

[38] (Wetzel, 1983). Wetzel, W. E. (1983). Angels and informal risk capital. Sloan Management Review, 24(4), 23-24.

[39] (Wong and Ho, 2007). Wong, P. K., \& Ho, Y. P. (2007). Characteristics and determinants of informal investment in Singapore. Venture Capital, 9(1), 4370.

[40] (Wong et al, 2005). Wong, P. K., Ho, Y. P., \& Autio, E. (2005). Determinants of angel investing propensity: Evidence from the global entrepreneurship monitor dataset. Frontiers of Entrepreneurship Research, 2(2).

[41] (World Bank, 2020). World Bank (2020). Doing Business 2020. Comparing Business Regulation in 190 countries. http://documents1.worldbank.org/curated/en/688761571934946384/pdf/Doi ng-Business-2020-Comparing-Business-Regulation-in-190-Economies.pdf

[42] (C) 2019 by the authors. Submitted for possible open access publication under the terms and conditions of the Creative Commons Attribution (CC BY) license (http://creativecommons.org/licenses/by/4.0/). 